\title{
Technical feasibility and impact of balinese cattle marketing toward income of the breeder in badung regency, bali
}

\author{
Ni Made Ayu Gemuh Rasa Astiti ${ }^{*}{ }^{*}$, and Siti Azizah ${ }^{1)}$ \\ ${ }^{1)}$ Study Program of Animal Husbandry, Faculty of Agriculture, University of Warmadewa \\ Faculty of Animal Science, University of Brawijaya
}

Submitted: 11 November 2019, Accepted: 26 November 2019

\begin{abstract}
The research was conducted from January to June 2018 at the animal market of Beringkit, Badung Regency, Bali. The objectives of the research were to study technical feasibility of Balinese Cattle breeding in Badung Regency, Bali, and the impact of Balinese cattle marketing toward the income of the breeders. The research is explorative research through a survey, which is designed as an explanatory research design. The method of research used a combination of qualitative and quantitative methods. The research was conducted toward the breeders of Balinese cattle on some markets in Badung Regency with 50 respondents of the research who were selected as purposive sampling. Criteria of the respondents include breeders who raise the brood cow. Instruments or tools of the research used the closed and structured questionnaires, which are equipped with open questions. Results of the research showed that technical feasibility of Balinese cattle breeding in Badung Regency, Bali, is considered to be appropriate because the stocks, cattle barn, feeds, and workforce that are utilized for public animal husbandry operation are always managed by the breeders, and the breeders are highly responsible for their cattle. The impact of Balinese Cattle marketing toward the income of the breeders is significant and the tendency of the breeders to sell their cattle when in urgent conditions cause low income for them.
\end{abstract}

Keywords: technical feasibility; income; Balinese cattle.

${ }^{*}$ Corresponding Author: ayugemuh@gmail.com 


\section{INTRODUCTION}

Bali has great potency for breeding stock of Balinese cattle. It is supported by the socio-cultural condition of the Balinese community who has propinquity with the cattle, in which the majority of the farmers in Bali, who live in a rural area, have cattle. Such a condition looks real in society with many groups of breeders or building villages as VBC (Village Breeding Centre) in Bali. Cattle breeding in Bali is conducted by small farmers in small-scale ( $1-3$ cows) (Putri, 2014). Such operations are usually integrated with other farming operations, which are utilized as deposits or just for pleasure. The main reason for breeding cattle is to increase the family's income by utilizing forage crops or other farming wastes as a by-product of rice-field, farm, and not-irrigated field (Sriyani, et al. 2018). Another reason why the breeders raise the cattle is to increase the family's prosperity (Astiti and Ni Ketut, 2016). To reach the prosperity, the breeders should pay attention to production techniques and marketing aspects. High production will not be able to increase their income optimally without accompanied by efficient marketing.

Efficient marketing will offer a higher price for breeders (Nazarudin, 2011). The increasing income will encourage the breeders to raise more cattle with favorable ways, such as providing qualified feeds and favorable mating systems, for example, implementing artificial insemination (AI), so that it will be able to increase the quality of the produced cattle. Indirectly, it will increase the cattle population in Bali. The success of cattle breeding cannot be separated from the marketing system. Therefore, such a condition must be improved to increase the breeders' prosperity. The objectives of the research were: (1) to obtain an obvious description of the technique in breeding the brood cow in Bali. (2) to find out the impact of Balinese cattle marketing toward the breeders' income.

\section{MATERIALS AND METHODS}

It is a survey research, which is designed as explorative research that is intended to explore deeply the phenomenon in the field. The research used a combination of qualitative and quantitative methods, in which the main approach is the quantitative approach. The marketing of Balinese cattle is conducted by analyzing functions of marketing, marketing channel, cost structure, cost, and structural analysis, behavior and market implementation.

\section{Location and Time of the Research}

The research was conducted at Badung Regency due to the biggest animal market of Beringkit in Bali is located in this regency. The location of the research was selected purposely. The research was conducted from January to June 2018.

\section{Type and Source of Data \\ Qualitative Data}

Qualitative data include:

1) Characteristics of the respondent, such as age, numbers of family members, numbers of the raised brood, cattle barn model, and feeding system, as well as reproduction of Balinese cattle.

2) Cost and income of the breeder, and

3) Marketing data: the age of selling the cattle, selling price of the bull and the cow, a problem faced by the Balinese cattle breeders in Badung Regency, Bali.

\section{Quantitative Data}

Quantitative data include numbers of breeder who raise Balinese cattle in Bali, numbers of the marketed bull and cow, numbers of Balinese cattle production in Badung Regency, Bali, the expensed marketing cost in the cattle marketing process through marketing agencies, as well as prices for male (bull) and female (cow) during the research.

\section{Data Source}

Primary data was derived from direct observation and interviews with the related individual using questionnaires, as an instrument, which have been constructed following the problems and objectives of 
the research. Secondary data was derived through documents or data of the cattle breeders, which include activities in operating the techniques of raising and marketing the Balinese cattle (Singarimbun, 1989).

\section{Data Collection Techniques}

Data of the research was collected through four ways, namely direct interview using structured questionnaires that have been prepared before, in-depth interview using open questions as guidance for interview and observation by observing activities in raising and marketing the Balinese cattle.

\section{Instrument of the Research}

Instrument of the research refers to tools used to collect the data. The collected data includes primary and secondary data.
Primary data was derived from direct observation on activities and interview the related individuals using instruments in the form of questionnaires or a list of questions, which have been constructed before that relate to the problem and objective of the research.

Instruments or tools are very important in research because these favorable instruments, information, and data, which are relevant to the objective of the research, can be obtained, so that such instruments must have high validity and reliability.

\section{Technical Feasibility of the Farming Operation}

Variables of management on raising the brood cow are measured by indicators and parameter as presented in Table 1.

Table 1. Indicator and Parameter of Technical Feasibility

\begin{tabular}{lll}
\hline Indicator & Parameter & Measurement \\
\hline & 1. Stock selection (prospective brood) & Ordinal Scale \\
2. Stall & $\begin{array}{l}\text { Ordinal Scale } \\
\text { Ordinal Scale }\end{array}$ \\
3. Feeding & Ratio Scale \\
& 4. Workforce & Ordinal Scale \\
5. Disease prevention & Ratio Scale \\
6. Reproduction & \\
& 1. Ways of Selling Cattle & Nominal Scale \\
Marketing Aspect & 2. Selling Prices of Male and Female Cattle & Ratio Scale \\
& 3. Selling Location & Nominal Scale \\
\hline
\end{tabular}

\section{RESULTS AND DISCUSSION General Description of Bali Province}

Bali Province is one of 34 Provinces in Indonesia. Bali Province comprises of Bali Island and small islands around it, such as Nusa Penida, Ceningan, Lembongan, and Serangan Islands, which lie at the southern part of Bali Island, and Menjangan Island lies at the western part of Bali Island. Geographically, Bali Province lies at: $8^{0}$ 03'40" - $8^{0} 50^{\prime} 48^{\prime \prime}$ South Latitude and $114^{0}$ $25^{\prime} 53^{\prime \prime}-115^{0} 42^{\prime} 40^{\prime \prime}$ East Longitude. In the center of Bali Island, a mountain range extends from West to East that includes
Mount Batukaru (2.276 m), Mount Batur (1.717 m), Mount Agung (3.142 m), and Mount Abang (2.276 m). At the North and South parts of the Mounts spread out plains. Badung Regency covers the area of 418.52 $\mathrm{Km}^{2}$, in which the land uses are intended for rice-field $29,970 \mathrm{Ha}$, not-irrigated field 8,191 Ha, plantation field $6,420 \mathrm{Ha}$, community forest $2,122 \mathrm{Ha}$, abandoned land $231 \mathrm{Ha}$, land utilized for pond/embankment $2,811 \mathrm{Ha}$, and land for other purposes (street, housing, office, etc.) $11,882 \mathrm{Ha}$. The number of populations in the Badung Regency was 543,332 peoples 
along with population density 1,298 individual $/ \mathrm{km}^{2}$ (BPS, 2017). Activities of the community at the northern part of the Badung Regency are dominated by plantation and agro-tourism activities. The northern part of Badung is adjacent to Buleleng Regency. The center part of Badung Regency, Mengwi Sub-district, lies at the altitude $0-350 \mathrm{~m}$ above sea level. Mengwi Sub-district is a rice-field area, which is dominated by agricultural activities and cultural-tourism. Activities of the community in the southern part of Badung are dominated by tourism, trade, and education center activities. The Southern part of Badung is directly adjacent to the Indonesian Ocean.

\section{Experience of the Breeder}

Experiences of the cattle breeders refer to times or periods that have been spent by the breeders in cattle breeding. Experiences become basic for knowledge development. In running a business, the breeders will find many new things. If those new things are being observed and learned as part of knowledge, so that times or periods, which have been spent in breeding cattle, will provide knowledge and skills for the breeders. Results of the research showed that the respondent breeders have sufficiently long experiences in cattle breeding, 17.8 years on average. Longer experiences in cattle breeding indicate that the respondent breeders have sufficient skills and knowledge in the management of cattle breeding. Experiences will affect the attitude, mindset, and behavior of the breeders in operating their business. Experience is a principle for knowledge. If someone works, he/she will find new things. If he/she has comprehended those new things like knowledge and he/she owns it, however, it means that he/she has got new work experience, and he/she has to practice, what he/she has learned, repeatedly and continuously in order to have great skills because by doing it regularly, the knowledge will be completed.

Table. 2. Cattle Population in Bali

\begin{tabular}{|c|c|c|c|c|c|c|c|c|c|c|c|c|c|}
\hline \multicolumn{14}{|c|}{ Beef Cattle } \\
\hline \multirow[b]{3}{*}{ No. } & \multirow[b]{3}{*}{$\begin{array}{l}\text { Regency/ } \\
\text { Municipality }\end{array}$} & \multicolumn{6}{|c|}{ Balinese Cattle (male) } & \multicolumn{4}{|c|}{ Balinese Cattle (female) } & \multirow[b]{3}{*}{ Sum } & \multirow[b]{3}{*}{ Total } \\
\hline & & \multirow[b]{2}{*}{ Calf } & \multirow[b]{2}{*}{ Young } & \multirow[b]{2}{*}{ Adult } & \multirow[b]{2}{*}{ Castrated } & \multirow[b]{2}{*}{ Sum } & \multirow[b]{2}{*}{ Calf } & \multirow[b]{2}{*}{ Young } & \multicolumn{3}{|c|}{ Adult } & & \\
\hline & & & & & & & & & $\begin{array}{c}2-4 \\
\text { years } \\
\text { old }\end{array}$ & $\begin{array}{c}5-6 \\
\text { years } \\
\text { old }\end{array}$ & $\begin{array}{c}>6 \text { years } \\
\text { old }\end{array}$ & & \\
\hline 1 & Denpasar & 651 & 613 & 206 & - & 1.470 & 1.018 & 1.317 & 1.729 & 1.371 & 336 & 5.771 & 7.241 \\
\hline 2 & Badung & 3.011 & 5.023 & 5.012 & - & 13.046 & 3.804 & 5.007 & 5.516 & 7.313 & 3.716 & 24.816 & 37.862 \\
\hline 3 & Gianyar & 5.131 & 5.901 & 4.758 & - & 15.790 & 5.896 & 5.965 & 10.382 & 5.572 & 3.256 & 31.071 & 46.861 \\
\hline 4 & Klungkung & 4.054 & 4.023 & 2.532 & 45 & 10.654 & 5.776 & 5.868 & 5.186 & 4.938 & 4.828 & 26.596 & 37.250 \\
\hline 5 & Karangasem & 13.207 & 18.795 & 21.086 & - & 53.088 & 12.669 & 15.949 & 16.747 & 19.706 & 4.140 & 69.211 & 122.299 \\
\hline 6 & Bangli & 8.558 & 17.390 & 18.593 & - & 44.541 & 5.511 & 8.259 & 6.660 & 5.780 & 4.413 & 30.623 & 75.164 \\
\hline 7 & Buleleng & 15.630 & 16.336 & 13.408 & 39 & 45.413 & 16.346 & 18.190 & 16.360 & 14.216 & 11.088 & 76.200 & 121.613 \\
\hline 8 & Jembrana & 7.081 & 3.322 & 2.634 & - & 13.037 & 7.205 & 9.710 & 8.205 & 8.050 & 6.099 & 39.269 & 52.306 \\
\hline 9 & Tabanan & 4.992 & 9.298 & 7.918 & 85 & 22.293 & 4.913 & 6.406 & 7.684 & 7.438 & 4.182 & 30.623 & 52.916 \\
\hline \multicolumn{2}{|c|}{ SUM: 2016} & 62.315 & 80.701 & 76.147 & 169 & 219.332 & 63.138 & 76.671 & 78.469 & 74.384 & 41.518 & 334.180 & 553.512 \\
\hline \multicolumn{2}{|c|}{ SUM: 2015} & 47.433 & 74.575 & 63.471 & & 185.489 & 45.243 & 59.730 & 71.309 & 76.821 & 39.554 & 292.657 & 478.146 \\
\hline \multicolumn{2}{|c|}{ SUM: 2014} & 75.051 & 99.631 & 92.350 & & 267.032 & 80.100 & 87.757 & 81.347 & 89.962 & 45.018 & 384.184 & 651.216 \\
\hline \multicolumn{2}{|c|}{ SUM: 2013} & 60.293 & 95.844 & 82.087 & & 238.224 & 60.588 & 80.813 & 96.433 & 107.491 & 53.924 & 399.249 & 637.473 \\
\hline \multicolumn{2}{|c|}{ SUM: 2012} & 89.482 & 101.287 & 94.813 & & 285.582 & 86.354 & 96.370 & & 215.440 & 398.164 & 683.800 & $\begin{array}{l}\text { SUM: } \\
2012\end{array}$ \\
\hline
\end{tabular}

Data Source: Department of Agriculture, Bali Province, 2017 


\section{Average Number of the Owned Cattle}

Numbers of cattle owned by the respondents range from 1-5 cows, and 3.96 cattle, which comprise of 0.68 bulls, 1.98 cows, 0.4 male calves and 0.9 female calf. Based on the results of the research, it showed that numbers of the owned cattle have not maximum about the breeders' ability in raising cattle. Nazir (1988) suggested that maximum ability of the breeders in raising brood is 5.03 broods, on average, with 3 cattle $(3.41 \%), 4$ cattle $(36.36 \%), 5$ cattle $(32.95 \%), 6$ cattle $(18.18 \%), 7$ cattle $(5.68 \%)$ with the same raising pattern as has been applied today. Besides not all medium breeders have calf and only $0.56 \%$ has male calf and $0.96 \%$ has a female calf.

\section{The Main Job of the Respondent}

The majority of the respondent breeders work as farmers /farm laborers $70 \%$, and just $6 \%$ of the respondent breeders work as cattle breeders, while $24 \%$ of the respondents work as retired civil servants, bricklayers, laborers, fisherman, agri-extension officer, and merchants. In general, it indicates that breeding cattle in Bali is a side job, and it has been proven by the result of the survey, in which $6 \%$ of the respondents work as cattle breeders. Astiti et al. (2016) reported that none respondent has the main job as a cattle breeder, however, their main jobs are as farmers (70 $\%$ ) and raising cattle is only as a side job to spend the leisure time alternating with the farming operation.

\section{Technical Feasibility of Breeding Balinese Cattle}

Feasibility in operating a business is an effort to assess whether the operation will be a success or not. Orientation to reach success for a business is the ability to gain profit. Feasibility in operating business in this research is assessed from the main aspect, the technical aspect.

\section{Stocks}

Balinese cattle have been established, based on the Decision of the Agricultural
Ministry Number: 325/Kpts/OT.140/1/2010, as native cattle from Indonesia and have spread over the entire area of Indonesia. Balinese cattle play an important role in supplying national beef. An important aspect of the production process of cattle breeding is the availability of stocks, which conform to the standard. Therefore, the standard for the cattle stocks should be established as a reference for the businessman to breed the Balinese cattle.

Standardization of Balinese cattle has set some requirements that relate to quality and how to measure the Balinese stocks. Balinese stocks have superior features and bequeath the features to their progenies and have met specific requirements to be bred. These standards have set the requirements for quality and how to measure the Balinese stocks. For quality, the requirements are differentiated between male and female Balinese stocks, which include qualitative and quantitative requirements. Qualitative requirements for female cattle, particularly for hide color, are as follow: reddish body, four lower legs are white, white bottoms with half-moon shape, tip of the tail with black tail hair, as well as black "eel line" on its back, short horns, long head shape and slim neck. The adult Balinese bull has a black body, lower legs below the knees are white, white bottoms with half-moon shape, tip of the tail with black tail hair, horns like a sickle shape that direct to the center, wide head shape, compact and strong neck, and medium size of the body.

\section{Stall}

Group of stalls are made in two types, such as single and double types by the needs and land shape. In the colony stall of a single type, the cattle are placed in one row. In colony stall of double type, the cattle are placed in two rows, which are set face to face. A path, \pm 1 -meter-wide, is in between those two rows, to facilitate in feeding and giving drinks to the cattle. In general, the group stalls, built by the respondent breeders, are colony stalls of double type. 
Two stalls are built with an average size of $5 \times 12$ meters each. So that the total width of the stalls is $120 \mathrm{M}^{2}$ for 32 broods. The stall type is double stalls, in which the cattle are placed in two rows, which are set face to face. A path, \pm 1 -meter-wide, is in between those two rows, to facilitate in feeding and giving drinks to the cattle.

Also, the single type is built. The stall size for each brood is $200 \mathrm{~cm}$ length and 150 $\mathrm{cm}$ in width. There is vacant land behind the stall along the stall building with \pm 1 -meter width for the brood exercise area. Tampubolon et al. (2011) suggested that stall size for the brood cow is $200 \mathrm{~cm}$ length and $150 \mathrm{~cm}$ width. The stall must be equipped with a wide yard for the broods to be able to move freely.

Feed

Success in cattle breeding is highly affected by the quality of the feed, besides genetic factors and management. The feed is forage, which comprises of grasses, legumes, and farming/plantation wastes. Grasses and legumes are derived by planting them in their land and the group or looking for them around the location. While agricultural/farming wastes are derived from their farming wastes or others. Forages for feed may be gained for free, but the breeders just need workforce and time to look for the forage and transporting cost to transfer the forages into the stall.

The amount of the forage application is $25.37 \mathrm{~kg} / \mathrm{ST} /$ day, twice (2) a day. Fresh forage is given at least $10 \%$ of the cattle weight. The forage should contain some forage that may complete the nutrients. Kinds of forage given by the respondent breeders are varied, such as grasses (wideleaved grass and field grass) and legumes (gamal (Gliricidia sepium), waru (Hibiscus tiliaceus), lamtoro (Leucaena leucocephala), and jackfruit (Artocarpus Integra), straws, corn stem, as well as bran if the respondent breeders have extra money to buy it. The drinking water is given a saline solution to increase the palatability/appetite of the cattle (Santoso, 1997).
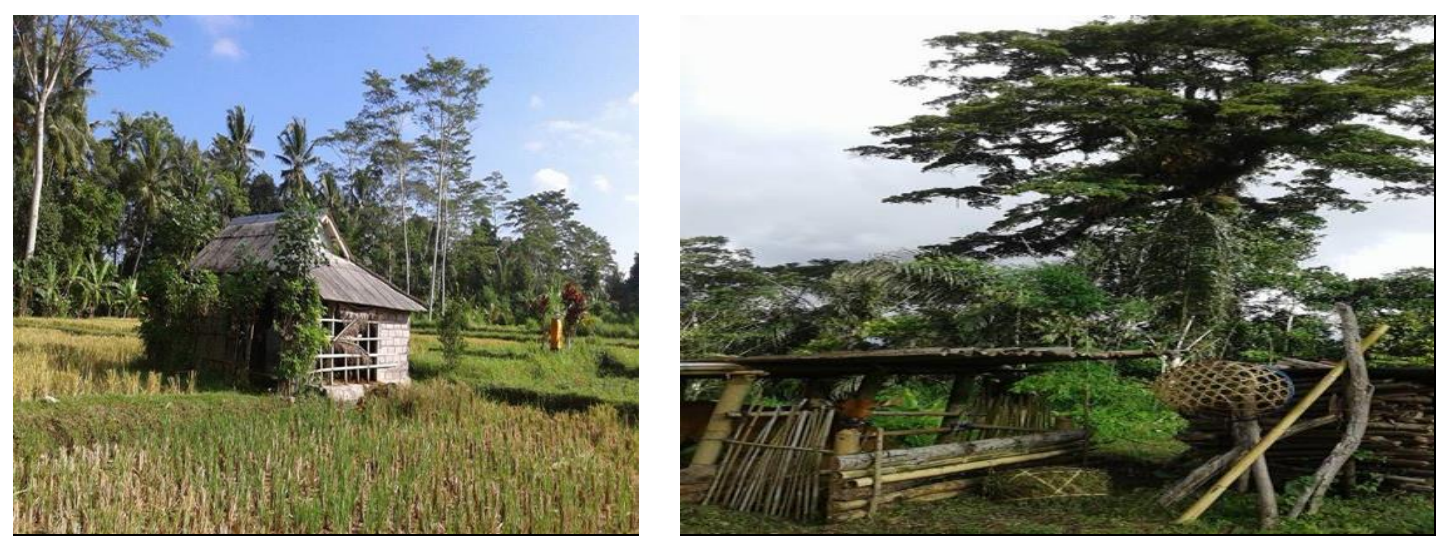

Figure 1. Individual Stall

\section{Workforces}

Workforces in cattle breeding are usually derived from themselves and/or their families. The workforces may comprise of 1-2 persons, husband, and wife. They may not receive any reward from this cattle breeding, and they never take into account the time they have spent in breeding their cattle (Soekartawi, 1993). The need for workforces in the Balinese stock breeding is 3.56 Man Workday Equivalent (MWDE) per cattle unit (CU) per month. $1 \mathrm{MWDE}$ is equivalent to the male workday for 8 days per day. $1 \mathrm{CU}$ is equivalent to 1 adult cattle, above 2 years old. Therefore, to raise 1 adult cattle, it requires 56.91 minutes per day, on 
average. The need for workforce (MWDE/CU) in operating the Balinese cattle breeding is fairly high. It may be due to the breeders have spent much time to search for grasses, 1.24 hours/day, on average, with raising 2.27 broods per breeder, on average.

\section{Disease Prevention}

Success in cattle breeding is not only seen from the increasing numbers of the cattle but how the breeders can raise and supervise their cattle so that their cattle will grow well and healthy. Disease prevention is conducted by giving vitamin and vaccine to the cattle periodically. One of the infectious diseases that commonly attack cattle is Septicaenia Epizooticae (SE), which is so-called in Indonesia as "snoring". This is considered as an acute disease and may cause death (Priyanto, 2016). In controlling such disease (SE), the prevention may protect the cattle for 6-12 months. By giving vitamin to the cattle, it will increase their resistance to the disease and increase both production and reproduction; however, the common vitamin given to the cattle is B complex through injection, once in 3 months. The calf is given vitamin and anthelmintic 1.5 months. Besides giving vitamin and vaccination, the breeders spray the cattle, stalls, and environment around the stalls using insecticide solution.

\section{Reproduction}

Success in reproduction is one of the important factors in determining the success of cattle breeding. Reproduction management applied by the respondent breeders has been run well, which is guided by the Department of Animal Husbandry and BPTU of Balinese cattle. Success of the reproduction management can be seen from the increased performance on cattle reproduction. Performance of the cattle reproduction is seen from many factors, such as 1) age of the first mating; 2) service per conception (s/c); 3) Calving interval; 4) Calf crop; 5) Calving frequency before culling; 6) calf mortality; and 7) brood mortality.
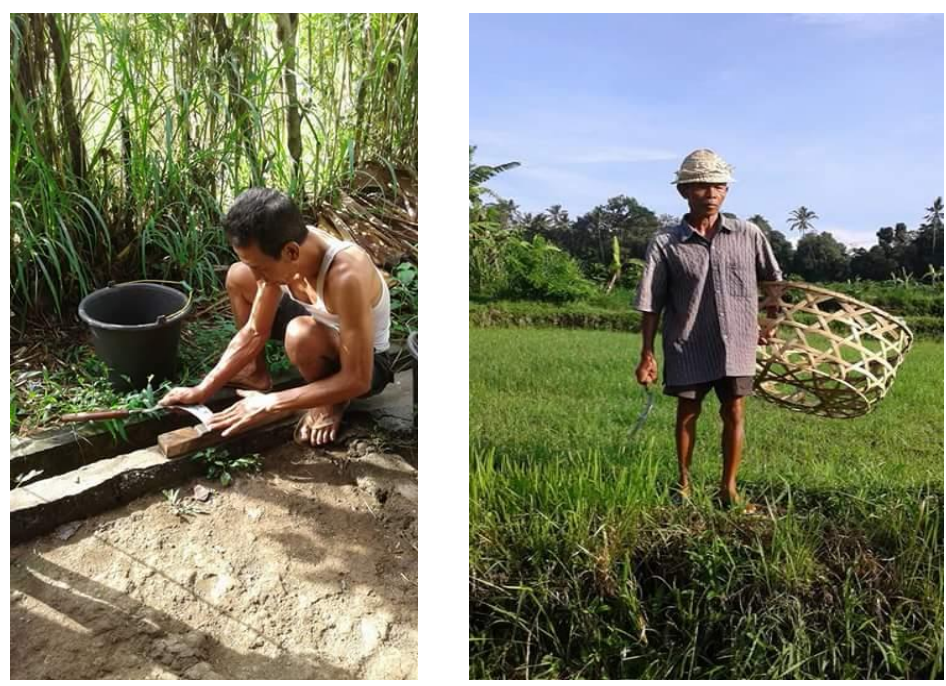

Figure 2. Workforce to look for feeds

The majority of the respondent breeders $(100 \%)$ apply Artificial Insemination (AI) as a mating method. For one mating costs 50.000,- - 75.000 - IDR /brood with an average price of 52,880.12
IDR /brood. The amount of the costs depends on distance (location) of stall and numbers of cattle that will be taken for mating. Balinese cattle have first puberty at 18-26 months. To increase the success of 
conception, in general, the first mating is conducted at the first estrus. [8] On average, the broods are 26.88 months, when they have been mating for the first time. Service per conception is several mating $\mathrm{AI} / \mathrm{NM}$ (service) or Artificial Insemination/Natural Mating, which is required by female cattle to have conception. Based on the previous research, it showed that service per conception $(\mathrm{s} / \mathrm{c})$ of the Balinese cattle is 1.25; higher than the cattle breed of Ongole (PO) and Limousine by s/c values are 1.28 and 1, respectively (Suryani, et al. 2017). Calving interval (CI) is the number of days/months between the calving and the next one. Range of the calving interval is reflection of the cattle fertility, calving interval can be measured by lactation time plus days open, and conception period. CI value for Balinese cattle on VBC under guidance by BPTU is 13.55 months lower than the value suggested by (Suryani et al. 2017) who reported that CI value for the Balinese cattle in Bali is 14.0, and 154 in Nusa Tenggara Timur (NTT), 160.0 in Nusa Tenggara Barat (NTB), and 15.7 in South Sulawesi.

Calf crop is a percentage for numbers of calf that were born alive in the last year. Percentage of calf crops for the Balinese cattle on VBC under guidance by BPTU is $82.94 \%$, the mortality of calf is $5.95 \%$ and mortality of the brood is $1.27 \%$. It indicates that Balinese cattle have some superiority in reproduction in comparison with local cattle or crossbreed cattle. Besides that, Balinese cattle can live with low qualified feeds, resistant to hot weather, and high percentage of carcass. These superiorities have increased the demand for the cattle to be bred, as stocks and as the beef cattle.

Balinese cattle can reproduce up to 12-15 years old. However, to obtain favorable stocks, the brood cows should be culling after 7-8 times calving or after their ages are 9-10 years old. Based on the previous research, the breeders have to cull their brood cows, on average, after 8.73 times calving. Appropriate time for culling is usually based on observation of the breeders when the cattle reproduction reduced and decreasing the quality of the resulted calf continuously.

The mortality level of the calf and the brood cow highly affect on income level of the breeders. The breeders may bear great loss if mortality of the brood and the calf take place. To decrease the mortality level, the breeders have applied favorable breeding management and increase prevention efforts against the disease. The mortality level of calves in this research was $5.95 \%$ and the mortality level of the brood cow was $1.27 \%$. The mortality level is smaller than the mortality level of the Balinese calf, which is raised in four different locations, such as Bali, NTT, NTB, and Sulsel for about $8.5 \% ; 48.0 \% ; 15.0 \%$; and $8.0 \%$, respectively. In general, the main causes of calf death on intensive breeding are 1) stress due to lack of feed/brood's milk, 2) less favorable breeding management, and 3) diseases.

\section{Marketing System}

Marketing is the spare head of success in doing business, as well as one of the eye chains of agri-business systems on animal husbandry that plays an important role in developing commercial operations. Based on the result of the research, cattle marketing, which is done by the respondent breeders, has not well-managed. The majority of the breeders are still focused on the production sector (on-farm) and they have not thought about the available opportunity to enter the market directly.

Most of the cattle marketing is conducted at each location of the stall because the breeders are scared of whether their cattle may get injured during the transporting. Therefore, the breeders are more pleasure if they sell the cattle in the stall. The buyers are usually middlemen, who buy the cattle and resell it to the animal market, or other breeders, who buy it for their breeding. The selling price of the cattle 
is determined by the buyer, but in general, the breeders have been informed by other breeders, who had sold their cattle, as well as by the middlemen. The Balinese cattle sales are conducted by cawangan system/without weight measured first. The calf is sold when its age 7.37 months, on average, by selling price is 5,750,000.IDR/cattle for male calf and 2,900,000.IDR /cattle for female calf. The prices were valid during the research in June 2018, when the religious days of Galungan and Idul Fitri were celebrated in almost simultaneously.

At that time, the Balinese community required many expenses for their religious days, therefore, they sold the calf and brood, and the price for the calf went down drastically because, on the other side, the demand for beef by the Moslem was increased. Beef is derived from the beef cattle, not the calf. The brood cows were sold (culling) when their reproduction reduced, on parity $8-9$, and 8.73 , on average. The culling brood was sold 6,750,000.- IDR /cattle, on average. The price of the culling broods is highly affected by the condition of the cattle, the fatter cattle get the higher price. The selling price has a significant difference in comparison with the selling price in the animal market, from 1,000,000.to 2,000,000.- IDR per cattle. Cost to rent a vehicle, which transports the cattle from the stall to the animal market is 150,000 .- IDR by capacity of 5 cattle.

However, such different prices have not able to motivate the breeders to sell their cattle to the animal market directly. It is due to they are afraid and they do not want to take any risk that their cattle may not be sold out $(87.96 \%)$, they feel more comfortable and easy if they sell it in the stall $(7.87 \%)$, and the other reason is the distance between the stall and the animal market, limited transportation line and anxiety to be fooled by the middleman in the animal market $(4.17 \%)$. Such a feeling of fear to take the risk is due to the lack of entrepreneurship spirit of the breeders (Soekartawi, 1993) so that they always feel comfortable with the current condition. Significant difference in selling prices between the male and the female calf has led the breeders prefer to raise male calf to the female ones, and their investment may circulate rapidly. The male calf is raised for 1.5 - 2 years, and they can be sold at a high price, moreover, the breeders may forecast the selling price of their cattle during Idul Fitri Day, in which the selling price must be higher.

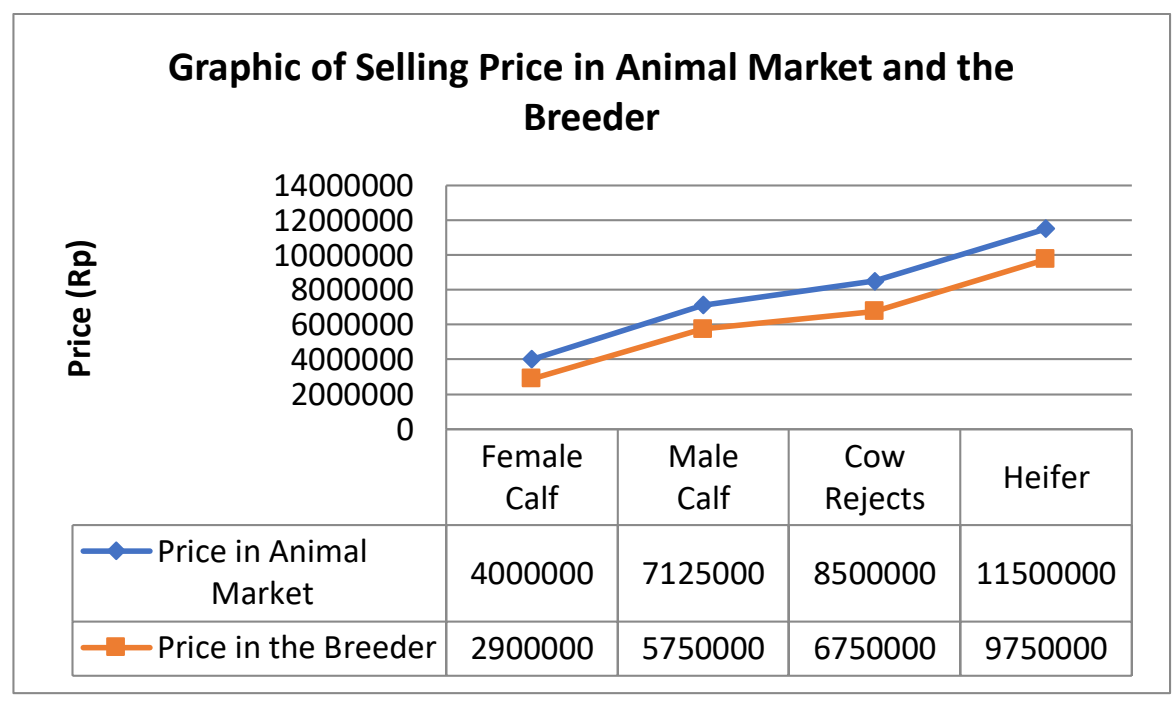

Figure 3. Different Selling Prices in the hand of the Breeder and Animal Market 
Characteristics of an entrepreneur are creative and innovative in facing the available opportunity; they are courageous to take the risk; they have managerial ability in designing, coordinating, supervising, and evacuating the business operation; they have leadership. spirit (Santoso, 1997), entrepreneurship is the ability to create and provide a product that has added value and implement efficient work through courage in taking risk, creativity and innovation, as well as managerial ability to search and take the opportunity. An individual, who dares to take the risk, is usually more innovative than an individual who has no courage to take any risk. There are great potency and opportunity to increase the income of the Balinese cattle breeders, but they have not been well-utilized by the breeders. Efforts to increase the entrepreneurship spirit of the breeders through training and extension may become the best solution to create tough breeders and market-oriented. By the growing of entrepreneurship spirit, the breeders will endeavor to develop their business, following the current change, and they will be courageous to take the available opportunity.

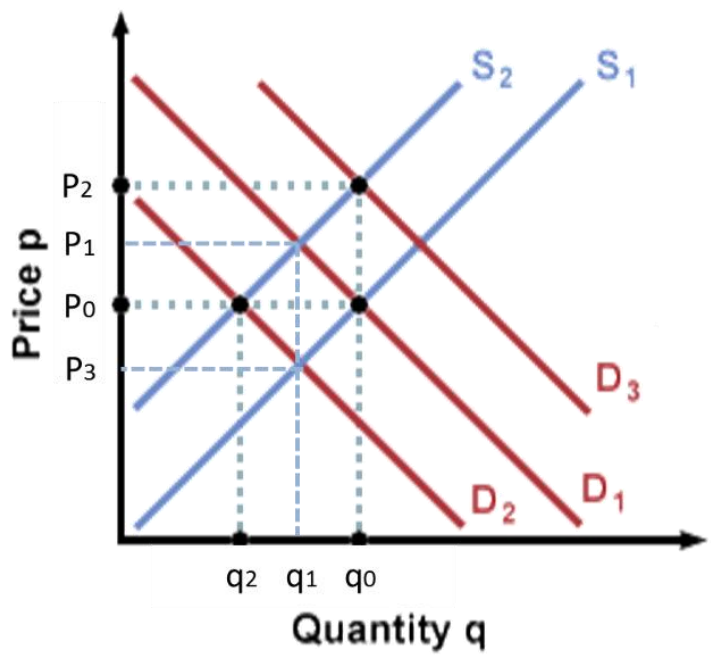

Description:

Figure 3. The Process in Setting Price of the Cattle
q0 = Big size
$\mathrm{q} 1$ = Medium size
$\mathrm{q} 2=$ Small size
$\mathrm{P} 0=$ The agreed price between the seller and the buyer for small size cattle
$\mathrm{P} 1=$ Price offered by the seller $\quad \mathrm{P} 2=$ Opening price set by the seller
P3 = Price offered by the buyer

\section{Process in Setting Price}

Setting the selling price of cattle is initiated by assessment. The prospective buyer may take a look at the cattle gender before they buy it and then followed by the bargaining process. At first, the breeders/traders open the price and then followed with the bargaining process between the breeders/traders and the buyers. The breeders/traders may set higher prices if they sell high qualified cattle based on sex (gender), age, and body size. On average, the sold cattle have variable sizes (small, medium, and big). The setting price process is presented in Figure 5. In which the breeders will open high price (P2) for medium size ( $\mathrm{q} 2)$, and then the prospective buyer will bargain the price below the price as set by the breeders previously (P3) and if any price agreement has not met, the breeders may reduce the bargaining price to position ( $\mathrm{P} 1)$, and finally the prospective buyers raise the bargaining to (P0) and the breeders reduce the bargaining price to $(\mathrm{P} 0)$, 
and at last the price agreement is set in (P0), both the breeders and the buyers feel satisfied and the price is agreed in position (P0).

\section{CONCLUSION}

Based on the technical feasibility in breeding the Balinese broods, the practice is considered appropriate due to the stock, stall, feed, and workforce for this cattle breeding have been well managed by the breeders, however, the breeders are very responsible for their cattle.

The impact of Balinese marketing toward the income of the breeder is significant, in which the breeders tend to sell their cattle when they require high costs in an urgent situation.

\section{REFERENCES}

Astiti, N. M. A. G. R., and Mardewi, N. K. (2016). Motivasi Peternak Dalam Menghasilkan Dan Memasarkan Pedet Sapi Bali Di Bali. In Tata Kelola Lingkungan Kepariwisataan Menuju Desa Wisata Berbasis Kearifan Lokal (pp. 13-19).

Astiti, N. M. A. G. R., Suparta, I. N., Oka, L., Gusti, I., and Antara, I. (2016). Marketing systems of calf Bali. International Research Journal of Engineering, IT and Scientific Research (IRJEIS), 2(11), 73-80.

BPS. (2017). Provinsi Bali dalam Angka. Bali.

I Ketut Sukada, I Gede Suarta2, and I Nyoman Warsa Parimartha3. (2016). The analysis of ruminant cattle potential as a source of meat production in East Nusa Tenggara Regency. International Research Journal of Engineering, IT and Scientific Research, 2(3).
Nazaruddin, R., Ilmu, D., Ternak, N., Peternakan, F., and Manajemen, D. (2011). Analisis strategi pemasaran peternakan ayam $\mathrm{CV}$ intan jaya abadi sukabumi. MANAJEMEN IKM: Jurnal Manajemen Pengembangan Industri Kecil Menengah, 6(2), 6473. https://doi.org/10.29244/64-73

Nazir, M. (1988). Metode Penelitian. Ghalia Indonesia.

Priyanto, D. (2016). Strategi Pengembangan Usaha Ternak Sapi Potong Dalam Mendukung Program Swasembada Daging Sapi Dan Kerbau Tahun 2014.

Putri, B.R. (2014). Strategi Manajemen Usaha Dan Sistem Agribisnis Perbibitan Sapi Bali Untuk Meningkatkan Pendapatan Peternak. Universitas Udayana.

Singarimbun, M. (1989). Metode Penelitian Survey. Jakarta: LP3S.

Soekartawi, S. (1989). E-Agribisnis: teori dan aplikasinya. Jurnal Fakultas Hukum UII.

Sriyani, N., Siti, W., Suarta, G., Partama, I. B. G., Ariana, N. T., and Yupardhi, W. S. (2018). Responses of corncob as replacement of elephant grass on performance and carcass profile of Bali Cattle. International Journal of Life Sciences (IJLS), 2(1), 42-49. https://doi.org/10.29332/ijls.v2n1.93

Tampubolon, P. F., Siregar, H., and Machfud, M. (2011). Strategi pengembangan usaha sapi perah skala mikro berwawasan lingkungan di Kabupaten Subang, Jawa Barat. MANAJEMEN IKM - Jurnal Manajemen Pengembangan Industri Kecil Menengah, 6(1), 37-43. https://doi.org/10.29244/37-43 